\title{
Musik Adaptasi Dangdut Madura
}

\section{Panakajaya Hidayatullah ${ }^{1}$}

Prodi Pengkajian Seni Pertunjukan dan Seni Rupa, Sekolah Pascasarjana, Universitas Gadjah Mada Yogyakarta

\begin{abstract}
ABSTRAK
Musik adaptasi dangdut Madura adalah bentuk penciptaan musik yang prosesnya dilakukan dengan mengadaptasi lagu asing (asal) menjadi lagu dangdut Madura (sasaran). Tujuan penelitian ini adalah untuk mengetahui proses adaptasi musik dangdut Madura dari lagu asal ke lagu sasaran melalui analisis musikologis. Analisis musikologis meliputi lirik, melodi vokal, dan hubungan antara lirik dan melodi vokal. Lirik dan melodi vokal dipilih sebagai objek studi karena keduanya merupakan unsur yang paling menonjol dalam musik adaptasi dangdut Madura. Hasil penelitian menunjukkan bahwa dalam proses adaptasi lagu asal ke lagu sasaran terdapat pola-pola atau kecenderungan yang sering terjadi yaitu: 1) lirik lagu sasaran selalu menyesuaikan dengan lirik lagu asal, penyesuaian tersebut melalui penyesuaian pola liris, pola tiruan bunyi (onomatope), pola penyesuaian bunyi dan saduran. 2) Melodi vokal lagu asal selalu berorientasi untuk tetap dipertahankan, tetapi mengalami perubahan yaitu penyesuaian ritme melodi vokal dan perubahan nada melodi vokal. 3) Terdapat hubungan lirik dan melodi vokal yang saling mempengaruhi dalam musik adaptasi dangdut Madura.
\end{abstract}

Kata kunci: adaptasi, dangdut, Madura

\begin{abstract}
The Musical Adaptation of Maduranese Dangdut. The musical adaptation of Maduranese dangdut is a form of musical creation process done by adapting a foreign song (origin) into a Maduranese dangdut song (target). The purpose of this study was to determine the adaptation process of Maduranese dangdut music from the origin song to the target one through musicological analysis. The musicological analysis includes the analysis of the lyrics, the vocal melodies, and the relationship between the lyrics and vocal melodies. The lyrics and vocal melodies were chosen as the objects of study because both of which were the most prominent elements in the musical adaptation of Maduranese dangdut. The results showed that in the process of adaptation tracked from the target to the original songs there are several patterns or tendencies that often occur. The patterns are the followings: 1) The lyrics targets always adjust to the lyrics of origin, these adjustments include the adjustment of lyrical pattern, the pattern of sound imitation (onomatopoeic), the pattern of sound adjustment and adaptation. 2) The melody of the original vocal songs are always designed to be retained, yet the changes are in the adjustment of the vocal melody rhythm and the tonal changes of the vocal melody. 3) There is a relationship between the lyrics and vocal melody which interplay in the musical adaptation of Maduranese dangdut.
\end{abstract}

Keywords: adaptation, dangdut, Maduranese

\section{Pendahuluan}

"Dangdut suara gendang, ditabuh-ditabuh berulang-ulang, dangdut suara gendang, sekarang ramai menjadi sebutan, ini musik melayu berasal dari Deli, lalu kena pengaruh dari Barat dan Hindi" (cuplikan lirik lagu Viva Dangdut ciptaan Rhoma Irama 1990).

Cuplikan lirik lagu di atas berasal dari lagu ciptaan Rhoma Irama yang berjudul Viva Dangdut.

1 Alamat korespondensi: Pengkajian Seni Pertunjukan dan Seni Rupa, Sekolah Pascasarjana, Universitas Gadjah Mada Yogyakarta, Jln. Humaniora, Bulaksumur, Sleman, Yogyakarta. E-mail: panakajaya.hidayatullah@ gmail.com; HP: 08990523702 
Tema dalam lagunya menjelaskan cara musik dangdut tercipta dan mengalami perkembangan. Rhoma Irama, dalam wawancara bersama Weintraub (2012) menjelaskan bahwa musik dangdut pada mulanya berawal dari kemunculan orkes-orkes melayu di era 1950 dan 1960-an. Musik dangdut mengalami metamorfosis pada era 1970-an, kemudian mendapat pengaruh dari musik Barat dan India. Berbeda dengan pendapat Rhoma Irama, Elvy Sukaesih beranggapan bahwa musik dangdut tidak berasal dari Melayu, tetapi karena terpengaruh oleh film India yang populer pada 1950 - 1960-an.

Frederick (1997: 257) menyebutkan bahwa istilah dangdut muncul sekitar 1972 - 1973. Musik ini digambarkan secara onomatopoetik dan merupakan istilah ejekan yang diambil begitu saja dari suara gendang. Penelitian tentang musik dangdut yang cukup komprehensif telah dilakukan oleh Weintraub (2012: 64). Penelitiannya dilakukan dengan mendekati asal-usul dangdut sebagai dialog global antar-budaya, yaitu musik populer India, Timur-Tengah, Eropa, dan Amerika Serikat yang diapropriasi, diterjemahkan, ditransformasi, dan diaduk dengan sensibilitas lokal Indonesia di pusat urban Jakarta dan Surabaya dekade 1950-an dan 1960-an.

Berdasarkan latar belakang di atas dapat disimpulkan bahwa musik dangdut merupakan percampuran/adaptasi beberapa produk budaya (musik) yang diapropriasi menjadi genre baru. Greenberg (Hutcheon, 2006: 7) dalam buku Theory Of Adaptation mengatakan bahwa adaptasi adalah pengulangan, tetapi tanpa peniruan dan terdapat banyak kemungkinan atau tujuan yang berbeda dibalik suatu tindakan adaptasi (Greenberg dalam. Terdapat desakan dalam diri setiap pelaku adaptasi untuk mengambil atau mengurangi substansi karya yang telah diadaptasi, mereka seolah-olah perlu untuk membayar upeti dengan cara menyalin sebagian dari karya asal sebagai penghormatan. Pernyataan tersebut menjelaskan bahwa antara karya asal dan karya sasaran dalam proses adaptasi pasti memiliki perbedaan. Namun, dalam setiap perbedaannya selalu ada unsur-unsur yang masih dipertahankan. Sejalan dengan pendapat Hutcheon yang menyatakan bahwa penciptaan karya adaptasi adalah suatu tindakan yang berhubungan dengan proses apropriasi, pemertahanan, dan interpretasi atas sebuah karya asal untuk menciptakan suatu karya baru.

"What ever the motive, from the adapter's perspective, adaptation is an act of appropriating or salvaging, and this is always a double process of interpreting and then creating something new" (Hutcheon, 2006: 20)

Hal tersebut dapat diamati pada beberapa karya musik dangdut yang dalam proses penciptaannya mengadaptasi musik asing seperti dicontohkan Weintraub. Salah satu lagu yang dinyanyikan Ellya Khadam berjudul Termenung, lagu tersebut merupakan lagu yang diadaptasi dari lagu Chhup Gayaa Koii Re Duur Se Pukaar Ke dalam film India berjudul Champakali (1957). Selain Ellya Khadam, raja dangdut Rhoma Irama juga pernah melakukan hal yang sama yakni mengadaptasi lagu film India. Adapun lagu-lagu Rhoma Irama yang mengadaptasi lagu film India di antaranya: Kata Pujangga yang mengadaptasi lagu Bol Radha Boi dari film Sangam (1964); Purnama yang mengadaptasi lagu Neele Gagan Ki Tale dari film Hamraz (1967); Gulali yang mengadaptasi lagu Aane Se Uske Aaye Bahar dari film Jeene Ki Raah (1969).

Adaptasi musik asing ke dalam musik dangdut di Indonesia juga dapat dilihat pada periode 2000-an. Penulis menambahkan beberapa contoh data tentang musik adaptasi yang dikumpulkan melalui media internet yaitu Youtube. Beberapa data yang telah didapatkan antara lain: lagu Mimpi Manis dinyanyikan oleh Dewi Persik dengan mengadaptasi lagu Dus Bahane Ost Dus dan lagu Sohiba dinyanyikan oleh Rhoma Irama dengan mengadaptasi lagu $O$ Saiba.

Pada era yang sama antara 1990-an dan 2000an, fenomena dangdut lokal juga mulai berkembang di setiap penjuru Indonesia. Musik dangdut lokal yang berkembang dinyanyikan dengan bahasa daerah dan biasanya dipasarkan pada kalangan komunitas etnik tertentu. Weintraub (2012: 234) mengatakan bahwa "Setelah jatuhnya Soeharto, "dangdut etnik" jenis lain (yang akan saya sebut "dangdut daerah") menggenangi kancah lokal di banyak belahan negeri ini”. 
Fenomena tersebut juga terjadi pada musik dangdut di Jawa Timur, terutama di daerah etnik Madura dan di daerah Situbondo khususnya. Industri musik dangdut lokal lahir dari kegelisahan para seniman dangdut daerah yang kesulitan untuk masuk industri musik nasional di masa itu. Menurut Anto selaku operator (Sound Enginer) pada salah satu perusahaan rekaman lokal di Kabupaten Situbondo, "kesulitan itu dikarenakan oleh biaya produksi saat itu sangat mahal, biaya untuk produksi satu lagu di perusahaan rekaman nasional sama seperti biaya produksi satu album produksi lokal" (Komunikasi pribadi, 3 April 2015). Hal tersebut sesuai dengan pernyataan Weintraub (2012: 237) bahwa "Krisis ekonomi (krisis moneter atau "krismon") yang mengguncang Asia Tenggara pada 1997 berefek penting pada pertunjukan, rekaman, dan distribusi dangdut".

Para seniman dangdut Situbondo Jawa Timur kemudian memanfaatkan industri rekaman lokal untuk tetap berkarya. Hasil karya tersebut lalu didistribusikan dan dijual kepada pasar mereka sendiri. Karya yang diciptakan berbahasa Madura, menyesuaikan target pasar yang mayoritas merupakan etnik Madura. Musik dangdut Madura dalam hal ini bukanlah musik dangdut berunsur musikal Madura, tetapi lebih mengarah pada bahasanya saja yang menggunakan bahasa Madura. Munculnya beberapa karya musik dangdut Madura, sebagian juga mengadaptasi musik asing.

Dalam penelitian ini dibahas tentang proses kreatif dalam musik adaptasi dangdut Madura melalui analisis musikologis. Adapun beberapa penelitian yang relevan berhubungan dengan adaptasi karya seni di antaranya: artikel yang telah ditulis oleh Agus Salim (2010: 106) berjudul Adaptasi Pola Ritme Dangdut pada Ansambel Perkusi dan artikel Philipus Nugroho Hari Wibowo (2012: 31) berjudul Ande-ande Lumut: Adaptasi Folklor ke Teater Epik Brecht. Karya Agus Salim membahas tentang proses adaptasi dari pola ritme musik dangdut ke dalam bentuk ansambel perkusi, sedangkan karya Wibowo membahas tentang adaptasi sebuah karya folkor berjudul Ande-ande Lumut ke dalam bentuk baru yaitu teater epik. Relevansi dari masing-masing penelitian tersebut terletak pada proses adapatasi dalam penciptaan suatu karya seni, sedangkan perbedaannya terletak pada obyek dan metodologi yang digunakan.

\section{Musik Dangdut Madura}

Musik dangdut Madura yang dibahas dalam penelitian ini bukanlah musik dangdut yang menggunakan unsur musik etnik Madura, tetapi yang dimaksud adalah musik dangdut berbahasa Madura. Musik dangdut Madura ini mulai berkembang pesat pada era 1990-an sampai 2000-an di Jawa Timur, khususnya di Kabupaten Situbondo. Musik dangdut Madura berawal ketika para seniman menyiasati krisis ekonomi yang terjadi kala itu. Mahalnya ongkos produksi di perusahaan rekaman nasional tidak membuat para seniman berhenti berkarya. Mereka memproduksi musiknya melalui industri musik lokal. Industri lokal bertugas merekam, memproduksi, dan memasarkan hasil karya para seniman lokal. Industri ini bersifat lokal dan dikemas dalam bahasa Madura, karena pangsa pasarnya hanya masyarakat lokal yang berbahasa sama saja. Menurut Angga selaku seniman dan ketua komite musik DKS (Dewan Kesenian Situbondo), "Dahulu pasar atau pemasaran musik dangdut Madura, ke arah barat sampai Kabupaten Pasuruan, ke arah Selatan sampai Kabupaten Lumajang, ke arah timur sampai Kabupaten Banyuwangi, dan ke arah utara sampai Kabupaten Sumenep Madura” (Komunikasi pribadi, 3 April 2015). Adapun hasil karya tersebut dikemas dalam bentuk kepingan VCD, dijual dengan harga murah dan biasanya beredar di lapak-lapak pedagang kaki lima. Hal yang serupa juga terjadi dalam beberapa musik dangdut lokal di Indonesia (Weintraub, 2012: 238). Bahkan ketenaran seorang artis dangdut Inul Daratista kala itu juga menggunakan strategi penjualan yang sama (Heryanto, 2012: 39). Sedikit berbeda dengan Inul, rekaman audio visual yang ditampilkan dalam VCD musik dangdut Madura, bukanlah hasil rekaman langsung (rekaman pentas), tetapi berupa rekaman video clip (video yang dikonsep khusus untuk sebuah karya lagu).

Di dalam penelitian ini penulis telah mengklasifikasi beberapa jenis lagu dangdut Madura dari tahun 2000-an sampai sekarang berdasarkan teknik penciptaannya. Beberapa data berupa 
video tersebut didapatkan melalui media internet Youtube. Data yang diambil adalah lagu dangdut berbahasa Madura, sebagian merupakan produksi lokal Situbondo dan sebagian lagi dari daerah lain. Adapun klasifikasi lagu dangdut Madura dari beberapa data yang berhasil dikumpulkan terdiri dari lagu original dan lagu adaptasi.

Lagu original adalah lagu dangdut Madura yang proses penciptaannya asli atau bukan merupakan adaptasi dari lagu lain. Istilah original, umum dipakai oleh para pelaku di Situbondo untuk menandakan proses penciptaan musiknya bukanlah berbentuk adaptasi. Adapun beberapa lagu dangdut Madura yang original di antaranya: lagu Sello' Soca Mera, ciptaan Asmuri Rafi, dinyanyikan oleh S.Pandi bersama Asmi Utami. Lagu Lek Marni, ciptaan Bambang S., dinyanyikan oleh Imam S. Wahyudi. Dua lagu di atas merupakan contoh dari lagu dangdut Madura yang original.

Lagu adaptasi adalah lagu dangdut Madura yang proses penciptaanynya mengadaptasi lagu asing (lagu lain), seperti halnya lagu dangdut nasional yang juga mengadaptasi lagu asing. Adapun beberapa lagu dangdut Madura yang mengadaptasi lagu asing dapat dilihat pada tabel 1 .
Dari data tersebut, klasifikasi lagu dangdut adaptasi dibagi menurut sumber lagu asal. Klasifikasi tersebut di antaranya adalah adaptasi dari lagu dalam film India, lagu Indonesia, lagu Melayu, dan lagu Campursari. Beberapa bagian dari lagu adaptasi dangdut Madura di atas kemudian dijadikan sampel untuk dianalisis secara mendalam. Analisis musikologis yang dibahas meliputi analisis tentang lirik, melodi vokal, dan hubungan antara lirik dan melodi vokal dalam lagu adaptasi dangdut Madura. Melalui perbandingan antara lagu asal dan lagu sasaran dianalisis cara pola-pola yang sering digunakan dalam proses adaptasinya. Lagu asal merupakan lagu asli yang akan diadaptasi menjadi lagu dangdut madura contohnya adalah beberapa lagu film india dan lagu lainnya. Sedangkan lagu sasaran merupakan lagu yang tercipta dari proses adaptasi.

\section{Analisis Lirik Lagu Adaptasi Dangdut}

\section{Madura}

\section{a. Pola Liris}

Layaknya sebuah penciptaan puisi, penciptaan lirik juga sangat memperhatikan bunyi sebuah kata yang dirangkai dalam lirik.

\section{Lagu Asli}

Lagu Sasaran

\begin{tabular}{ll}
\hline Adaptasi Lagu Film India & \\
Chaha Hai Tujhko (Film Mann, 1999) & Asapo' Robena Dhika dan Abhekte \\
Chaiyya Chaiyya (Film Dil Se, 1998) & Cia Cia \\
Saajan Ji Ghar Aaye (Film Kuch-Kuch Hota Hai, & Hitam Manis
\end{tabular}

1998)

Dhoom-Dhoom (Film Dhoom, 2004)

Dil Ne Yeh Kaha Hai Dil Se (Film Dhadkan, 2000)

Humko Humise Churalo (Film Mohabbatein, Tak Bisa Mungker 2000)

\section{Adaptasi Lagu Indonesia}

Akhir Sebuah Cerita (Cipt. Friz Moneta) Yatim Piatu

Bunga-Bunga Cinta (Cipt. Alwi Hasan) Eman Onggu

\section{Adaptasi Lagu Melayu}

Laksmana Raja Di Laut (Cipt. Pak Ngah) Rato Sagere

\section{Adaptasi Lagu Campursari}

Sri Minggat (Cipt. Sonny Josz)

Kare Ngandung

Pengga' Taresna

Turu Nang Dadane (Cipt. Hawadin)

Maelang

Abental Dede 
Menurut teori simbolisme, tugas puisi adalah mendekati kenyataan ini, dengan cara tidak usah memikirkan arti katanya, melainkan mengutamakan suara, lagu, irama dan rasa yang timbul karenanya dan tanggapan-tanggapan yang mungkin dibangkitkannya (Pradopo, 2005: 23). Biasanya proses penciptaan lirik pada musik adaptasi lebih menonjolkan pada penyesuaian pola liris. Proses penyesuaian dilakukan untuk memudahkan proses adaptasi dan agar tercipta harmonisasi. Adapun pola rima yang dipakai dalam pembentukan pola liris adalah:

Rima a - a, pola rima tersebut terdapat dalam beberapa lagu sasaran. Salah satunya adalah lagu Asapo' Robena Dhika yang mengadaptasi lagu film India berjudul Chaha Hai Tujhko. Adapun pola rima yang dimaksud adalah:

\section{Chaha Hai Tujhko}

Chaha Hai Tujhko Chahunga Hardam

(aku akan selalu mencintaimu)

Mar Ke Bhi Dil Se Ye Pyaar Na Hoga Kam

(Walau aku mati cintaku tidak akan pernah berkurang)

\section{Asapo' Robena Dhika}

Anape bule nesser de' dika

(Mengapa aku cinta kepadamu)

Seang ben malem ngalembe'e mata

(Siang dan malam terbayang di mata)

Pada lirik lagu asal di atas terlihat pola rima a - a. Setiap kalimat diakhiri dengan akhiran bunyi “-am" pada kata Hardam dan Kam. Kemudian pada lagu sasaran, akhiran bunyi “-am" mengalami penyesuaian bunyi menjadi akhiran bunyi vokal "-a" dalam kata dika dan mata. Penyesuaian bunyi yang dilakukan adalah dengan menangkap pola rima pada lagu asal, kemudian disesuaikan dalam lagu sasaran dengan pola rima yang sama. Jadi penyesuaian bunyi dalam lirik lagu sasaran hanya pada pola rima-nya saja.

Selain potongan lirik di atas, analisis pada lagu yang sama juga dapat dilihat pada bagian yang lain, yaitu:

\section{Chaha Hai Tujhko}

Kya Yeh Zindgani Hai Bas Teri Kahani Hai (Apakah kehidupan ini, hanya ada ceritamu) Bas Teri Kahani Hai Ye Jo Zindgani Hai (Hanya ada ceritamu dan kehidupanku) Teri Woh Baatein Woh Chaahat Ki Rasmein (Kata katamu itu, ikatan cintamu itu) Jhoothey The Vaade Kya Jhoothi Thi Kasmein (Janji-janji yang palsu atau sumpah yang palsu)

\section{Asapo' Robena Dhika}

Gun kare neserra bule de' ka dika

(Hanya tinggal cintaku kepadamu)

Pera' kare emanna bule mon tak teka

(Sayang sekali bila aku tidak bisa mencapainya)

Comma rep ngarep edelem ate

(Hanya mengharap dalam hati)

Segghut dika detteng edelem mempe

(Sering kamu datang di dalam mimpi)

Pada analisis teks di atas juga ditemukan pola rima yang sama seperti analisis sebelumnya, yaitu penerapan pola rima dalam lagu sasaran yang menyesuaikan pola rima pada lagu asal. Pola rima pada teks di atas juga masih sama seperti teks sebelumnya, yaitu menggunakan rima a - a.

Rima $\mathrm{a}-\mathrm{b}$ dan penyesuaiannya, pola rima tersebut terdapat pada lagu Tak Bisa Mongker yang mengadaptasi lagu dalam film India berjudul Humko Humise Churalo, adapun pola rima yang dimaksud adalah:

\section{Humko Humise Churalo}

Hum zulfein to bikhra dein

(Jika aku membiarkan rambutku terurai)

Din meraatna ho jaaye

(Mungkin akan mengubah siang menjadi malam)

Hum anchaal to lehra dein

(Aku akan membiarakan selendangku terbang) Paar baraatna ho jaaye

(Tapi mungkin akan menyebabkan hujan turun)

Rasa niser delem dede

$$
\text { Tak Bisa Mongker }
$$

(Rasa sayang dalam dada) 
Posangnga pon tada' pade

(Kebingungannya pun tak ada yang sama)

Sanajjen benynyak agude

(Walaupun banyak yang menggoda)

Bule tak bisa aobe

(Aku tak bisa berubah)

Pola rima pada lirik lagu asal adalah $a-b$, dalam kalimat pertama diakhiri dengan bunyi “-ein", kalimat kedua diakhiri dengan bunyi “-aye”. Kemudian kalimat berikutnya mengulang pola rima dari kalimat pertama dan kedua. Pada lagu sasaran pola rima-nya mengalami penyesuaian menjadi a - a. Penyesuaian tersebut dilihat dari bunyi pada akhir kalimat, yaitu akhiran bunyi vokal "- $e$ ” di semua kalimat.

Selain pola di atas, juga ditemukan pola lain yang terdapat pada beberapa lagu sasaran. Salah satunya pada lagu Abhekte yang mengadaptasi lagu Chaha Hai Tujhko, yaitu:

\section{Chaha Hai Tujbko}

Chaha Hai Tujhko Chahunga Hardam

(Aku akan selalu mencintaimu)

Mar Ke Bhi Dil Se Ye Pyaar Na Hoga Kam

(Walau aku mati cintaku tidak akan pernah berkurang)

\section{Bagian 1}

Allahhu Allah maulana Rabbi

Allahhu Allah maulana Hasbi

\section{Bagian 2}

Allahhu Allah Wali Ghairihi

Allahhu Allah kullu bi mahya

Lirik pada lagu Abakthe merupakan adaptasi dari lirik lagu asal, tetapi mendapat pengulangan sebanyak dua kali. Pola rima pada lagu asal adalah a - a dengan akhiran bunyi “-am”. Pada lagu sasaran, bagian pertama menggunakan pola rima yang sama yakni a - a dengan akhiran bunyi "-bi", kemudian pada bagian kedua pola rima-nya mengalami penyesuaian menjadi $\mathrm{a}-\mathrm{b}$ dengan akhiran bunyi "-hi" dan " $-y a$ ". Penyesuaian dari pola rima a - a menjadi a b karena disesuaikan dengan lirik lagu sasaran yang menggunakan bahasa Arab dari bacaan Shalawat. Jadi dalam proses kreatif adaptasi dari lagu film India menjadi lagu Madura terdapat dua kemungkinan penyesuaian pola liris, yaitu penyesuaian dari rima pada lagu asal a - a menjadi $\mathrm{a}-\mathrm{b}$ dan $\mathrm{a}-\mathrm{b}$ menjadi $\mathrm{a}$ - a pada lagu sasaran. Dalam hal ini perubahan terjadi karena adanya penyesuaian antara kosakata bahasa asal dengan kosakata bahasa sasaran.

\section{b. Pola Tiruan Bunyi (Onomatope)}

Kata-kata yang dibentuk berdasarkan tiruan bunyi ini disebut kata peniru bunyi atau Onomatope (Chaer, 2009: 44). Onomatope atau tiruan bunyi banyak dijumpai dalam lirik lagu, puisi, atau bahasa keseharian. Unsur utama dalam onomatope hanya berupa bunyi yang tidak memiliki arti.

Penggunaan pola tiruan bunyi pada musik sasaran terdapat dalam lagu Kare ngandung yang mengadaptasi lagu film India berjudul Dhoomdhoom, sama seperti judul film tersebut. Pola tiruan bunyi yang dimaksud adalah:

\section{Dhoom-Dhoom}

Dhoom Dhoom come and light my fire (Dhoom Dhoom datang dan nyalakan apiku)

Dhoom Dhoom let me take you higher

(Dhoom Dhoom biarkan aku membawamu lebih tinggi)

Dhoom Dhoom I wanna feel that burnin'

(Dhoom Dhoom Aku ingin merasakan kehangatannya)

\section{Kare ngandung}

Dung dung bule kare ngandung

(Dung dung aku terlanjur hamil)

Dung dung bule duh pon ngandung

(Dung dung aduh aku terlanjur hamil)

Dung dung bule duh jek dina

(Dung dung aduh jangan tinggalkan aku)

Dhoom pada lagu asal merupakan onomatope dari bunyi sebuah ledakan, seperti dor dalam bahasa Indonesia atau bang dalam bahasa Inggris, sedangkan pada lagu sasaran, tiruan bunyi dhoom mengalami penyesuaian 
bunyi menjadi $d u n g$. Tiruan bunyi dung diambil dari repetisi (bentuk pengulangan) kata $d u n g-$ ngandung, dalam bahasa Madura mempunyai arti sedang hamil. Namun, dalam pemakaiannya, bunyi dung hanya digunakan untuk tiruan bunyi yang tidak memiliki arti. Dalam hal ini bisa dikatakan proses adaptasi lirik dari lagu asal ke lagu sasaran dilakukan dengan menangkap pola tiruan bunyi (onomatope) yang sesuai.

\section{c. Pola Penyesuaian (Orientasi) Bunyi}

Pola penyesuaian bunyi dalam lagu sasaran adalah proses adaptasi secara auditif. Menangkap pola bunyi lirik yang dihasilkan oleh lagu asal, kemudian pola bunyi tersebut disesuaikan dengan pola bunyi lagu sasaran yang menyerupai. Proses penyerapan bunyi yang menyerupai bunyi dalam musik asal ditentukan oleh ketersediaan kosakata pada lagu sasaran. Adapun contoh dari pola penyesuaian bunyi tersebut bisa dilihat dari lagu Cia-Cia yang mengadaptasi lagu film India berjudul Chaiyya Chaiyya dalam film Dilse.

\section{Chaiyya Chaiyya}

Chal chhaiyya chhaiyya chhaiyya chhaiyya Chal chhaiyya chhaiyya chhaiyya chhaiyya (Ayo, bayangan saya, bayangan, bayangan, bayangan)

Chhaiyya chhaiyya chhaiyya chhaiyya (Bayangan saya, bayangan, bayangan, bayangan)

\section{Cia Cia}

Aduh Cia cia cia cia tak andi' rokok cia cia (Aduh hambar, hambar, hambar, hambar, hambar, tak punya rokok hambar, hambar)

Cia cia cia tak andi' pesse cia cia (Hambar, hambar,hambar, hambar tak punya uang hambar)

Pada lirik Chaiya-Chaiyya, kata Chaiyya dalam bahasa India yang memiliki arti bayangan, kemudian diadaptasi ke dalam lagu sasaran menjadi kata Cia yang memiliki arti hambar dalam bahasa Madura. Penyesuaian bunyi dari kata Chaiyya menjadi kata Cia di sini bukanlah merujuk pada makna, tetapi melalui proses penyesuaian bunyi yang hampir sama. Jadi dalam lagu sasaran, proses adaptasi liriknya dilakukan dengan cara menyesuaikan bunyi pada lirik lagu asal berdasarkan ketersediaan kosakata yang sesuai, walaupun secara makna dan konteksnya berbeda.

\section{d. Saduran (Terjemahan)}

Sebagian musik dangdut Madura menggunakan teknik terjemahan dalam proses adaptasi liriknya. Proses adaptasi lirik dengan teknik terjemahan dibagi menjadi dua macam, yaitu teknik saduran langsung dan teknik saduran kontekstual. Teknik saduran langsung artinya lirik pada lagu sasaran mengandung makna yang sama dengan lagu asal dengan cara melakukan terjemahan kata perkata. Terjemahan kontekstual didasarkan pada kesesuaian makna lirik dalam lagu sasaran dengan lagu asal. Proses penerjemahan dilakukan dengan menyesuaikan konteks lagunya saja dan tidak diterjemahkan kata perkata.

Saduran langsung, contoh lagu yang menggunakan saduran langsung terdapat pada lagu Rato Sagere yang mengadaptasi lagu Laksmana Raja Di Laut. Di dalam lagu sasaran tersebut terdapat lirik yang merupakan hasil terjemahan langsung dari lirik lagu asal. Adapun lirik lagu tersebut adalah:

\section{Laksmana Raja Di Laut}

Zapin...... aku dendangkan

(Zapin........aku nyanyikan)

Lagu Melayu......pelipur hati......

(Lagu Melayu........penawar hati......)

Pelipur lara

(Penawar lara)

\section{Rato Sagere}

Gending...bule atembang

(Gending...aku nyanyikan)

Tembang Madura...panglepor ate

(Lagu Madura...penawar hati)

Panglepor sossa

(Penawar lara) 
Pada lagu asal, kata zapin yang merujuk pada sebuah tarian Melayu, kemudian pada lagu sasaran disadur menjadi kata gending yaitu sebuah bentuk musik dalam musik gamelan Madura. Secara maknawi kata zapin dan gending tidak sama, namun pemilihan kata gending dalam lagu sasaran dapat dilihat dari beberapa kemungkinan dalam proses adaptasi, antara lain: 1) Akhiran bunyi kata zapin adalah “-in”, sedangkan akhiran bunyi kata gending adalah "-ing". Kemiripan akhiran bunyi dari kata zapin dan gending inilah yang menjadi faktor pemilihan kata gending pada lagu sasaran, sehingga lagu sasaran yang menyadur lagu asal terlihat harmonis. 2) Keterbatasan kosakata bahasa sasaran yang sesuai dengan kata zapin pada lagu asal, memaksakan kata gending untuk dipakai dalam lagu sasaran karena secara konteks masih memiliki kedekatan yakni sebuah tarian dan musik. Kemudian pada kalimat berikutnya pola saduran secara langsung bisa terlihat dengan jelas, yakni alih bahasa langsung dari lagu asal yang menggunakan bahasa Melayu kemudian dialih-bahasakan menjadi bahasa Madura.

Saduran kontekstual, contoh lagu yang meng-gunakan terjemahan secara kontekstual terdapat pada lagu Abental dada yang mengadaptasi lagu campursari berjudul Turu nang dadane. Adapun lirik dari lagu tersebut adalah:

$\quad$ Turu Nang Dadane
Kepingin turu nang dadane
(Ingin tidur di dadanya)
Kepingin sun ngelus rambute
(Ingin aku belai rambutnya)
cagerno duh duh klendhi rasane
(Mengharapkan duh duh bagaimana rasanya)
keloron dadi lan nyatane
(berdua jadi kenyataan)

\section{Abental Dada}

Terrona neggu'a tanangnga

(Ingin memegang tangannya)

Terro tedhunga e dadana

(Ingin tidur di dadanya)

Aba' cellep terro anga'ah

(Diriku dingin ingin kehangatan)
Salemot ta' daddi ngiddena

(Selimut tidak membuat tidur nyenyak)

Pola saduran secara kontekstual terlihat jelas di dalam lagu sasaran, lagu sasaran memiliki makna secara kontekstual yang menggambarkan sebuah ungkapan keinginan seseorang untuk hidup bersama dengan seseorang yang didambakaannya. Hal ini sesuai dengan makna lagu asal secara kontekstual. Saduran kontekstual juga mengutamakan pola liris pada liriknya. Pola rima lagu asal adalah $\mathrm{a}-\mathrm{a}$, dengan akhiran bunyi vokal " $-e$ ” pada setiap akhir kalimat. Kemudian akhiran bunyi vokal "- $e$ ” pada lagu asal berubah menjadi akhiran bunyi vokal " $-a$ " pada lagu sasaran. Pola rima yang digunakan dalam lagu sasaran juga sama dengan pola rima lagu asal yaitu a $-\mathrm{a}$.

Selain lagu Abental dada, pola saduran kontekstual yang lain adalah pada lagu Rato Sagere yang mengadaptasi lagu Laksmana Raja Di Laut. Berikut lirik lagu tersebut:

\section{Laksmana Raja Di Laut}

Kembanglah goyang atas kepala

(Kembanglah goyang atas kepala)

Lipatlah tangan sanggul dipadu

(Lipatlah tangan sanggul dipadu)

\section{Rato Sagere}

Kembang alembay kembang malate

(Bunga melambai bunga melati)

Nyarekcek eattassa gellungnga

(Menempati di atas sanggulnya)

Saduran kontekstual tidak selalu memperhatikan jumlah kata di setiap kalimat/bait, artinya dalam setiap kalimat/bait, jumlah kata pada lagu sasaran tidak selalu sama dengan jumlah kata lagu asal. Seperti pada potongan lirik lagu Laksmana Raja Di Laut dan Rato Sagere. Pada kalimat kedua, jumlah kata pada lagu asal adalah empat kata sedangkan pada lagu sasaran jumlah katanya hanya tiga. Perubahan ini dikarenakan oleh proses penyesuaian kosakata ketika lirik lagu asal disadur dalam bahasa sasaran, akibatnya jumlah kata setiap kalimat/ 
bait dalam lagu sasaran tidak selalu sama dengan lagu asal. Jika dilihat dari melodi vokalnya, lagu sasaran berusaha untuk mengisi pola ritme dalam melodi vokal dengan beberapa kata/ suku kata agar terlihat sesuai seperti lagu asal. Penyisipan kata/suku kata ke dalam pola ritme melodi vokal akan terlihat melalui transkripsi pada notasi 1 .

Dilihat dari transkripsi pada notasi 1 tersebut, melodi lagu asal dan lagu sasaran adalah sama. Berarti dalam hal ini melodi vokal mempengaruhi dalam pemilihan lirik lagu sasaran. Jadi jumlah kata dalam kalimat/ bait pada lagu sasaran bukanlah hal yang dominan dalam proses adaptasi menggunakan pola saduran kontekstual. Hal yang paling dominan adalah cara pola ritme pada melodi lagu asal agar bisa diisi lirik menggunakan bahasa sasaran. Konsekuensinya adalah jumlah kata dalam setiap kalimat/bait lagu sasaran tidak selalu sama dengan lagu asal karena disesuaikan dengan melodi vokal.

\section{Analisis Melodi Vokal Lagu Adaptasi Dangdut Madura}

a. Penyesuaian Ritme pada Melodi Vokal

Ritme merupakan elemen waktu dalam musik yang dihasilkan dari durasi dan aksen (Salim, 2010: 106). Ritme merupakan unsur yang terpenting dalam sebuah musik selain melodi dan harmoni. Salim (2010: 106) menambahkan bahwa pola ritme adalah salah satu aspek dari struktur dasar musik yang meliputi antara lain: batteri rythmic, tone color, accent. Melodi vokal pada sebuah lagu memiliki rangkaian nada yang tersusun berdasarkan pola ritme tertentu seperti musik dangdut Madura.
Dalam musik adaptasi dangdut Madura, ciri dan karakter musiknya mengambil melodi vokal pada lagu asal. Selanjutnya ciri dan karakter melodi vokal lagu asal diaplikasikan menjadi melodi vokal lagu sasaran. Proses pengambilan melodi vokal ini tentunya tidak serta merta mengalami kecocokan secara langsung. Dalam prosesnya terdapat beberapa kemungkinan yang terjadi ketika melodi vokal pada lagu asal diterapkan ke dalam lagu sasaran. Perubahan tersebut adalah penyesuaian ritme pada melodi vokal lagu asal ke melodi vokal lagu sasaran. Adapun contoh penyesuaian ritme tersebut akan digambarkan pada notasi 2 dalam potongan notasi lagu Asapo' robena dika dengan lagu asalnya.

Pada notasi 2 tersebut dapat dilihat perbandingan melodi vokal lagu asal dan lagu sasaran. Di dalam birama pertama ketukan dua, pola ritme seperenam belasan dengan gaya melismatis lagu asal mengalami penyesuaian pada lagu sasaran menjadi gaya silabis (satu suku kata dinyanyikan oleh satu nada). Melismatis adalah gaya melodi yang berhubungan dengan musik vokal (namun secara teknis/estetis juga dipakai bagi musik instrumental), yaitu suatu suku kata mendapatkan berbagai nada daripada satu saja (Mack, 1994: 142). Begitu juga pada ketukan selanjutnya, yang semula pola ritmenya adalah seperdelapan kemudian berubah menjadi pola ritme seperempat. Pada birama ketiga dan keempat juga mengalami penyesuaian yang sama. Penyesuaian yang serupa juga terjadi pada lagu adaptasi lainnya.

Contoh yang lain adalah lagu Pegga' Taresna yang mengadaptasi lagu film India berjudul $D i l$ $\mathrm{Ne}$ Ye Kaha Hai Dil Se. Adapun penyesuaian tersebut akan digambarkan pada notasi 3 .

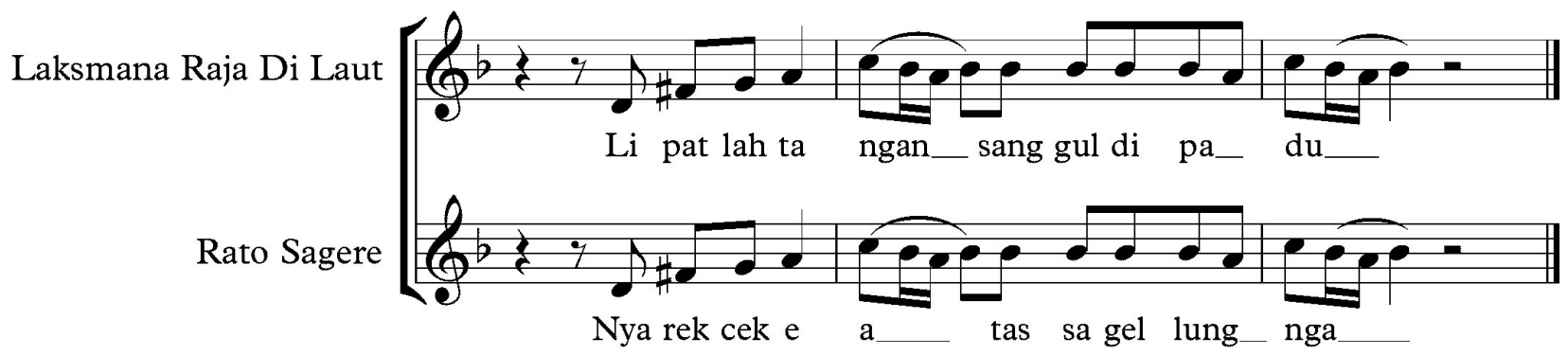

Notasi 1. Penyisipan kata/suku kata ke dalam pola ritme melodi vokal pada lagu Rato Sagere yang mengadaptasi lagu Laksmana Raja Di Laut 
Perbandingan pada notasi 3 tersebut terdapat penyesuaian pola ritme pada birama pertama ketukan keempat, yakni pola ritme dengan gaya silabis pada lagu asal kemudian mengalami penyesuaian menjadi pola ritme dengan gaya melismatis pada lagu sasaran. Pada birama kedua ketukan pertama dan ketukan ketiga, kemudian pada birama ketiga ketukan keempat juga terdapat penyesuaian ritme. Dari beberapa contoh perbandingan lagu di atas dapat dikatakan bahwa penerapan adaptasi melodi vokal ke dalam lagu sasaran tidak selalu sama,
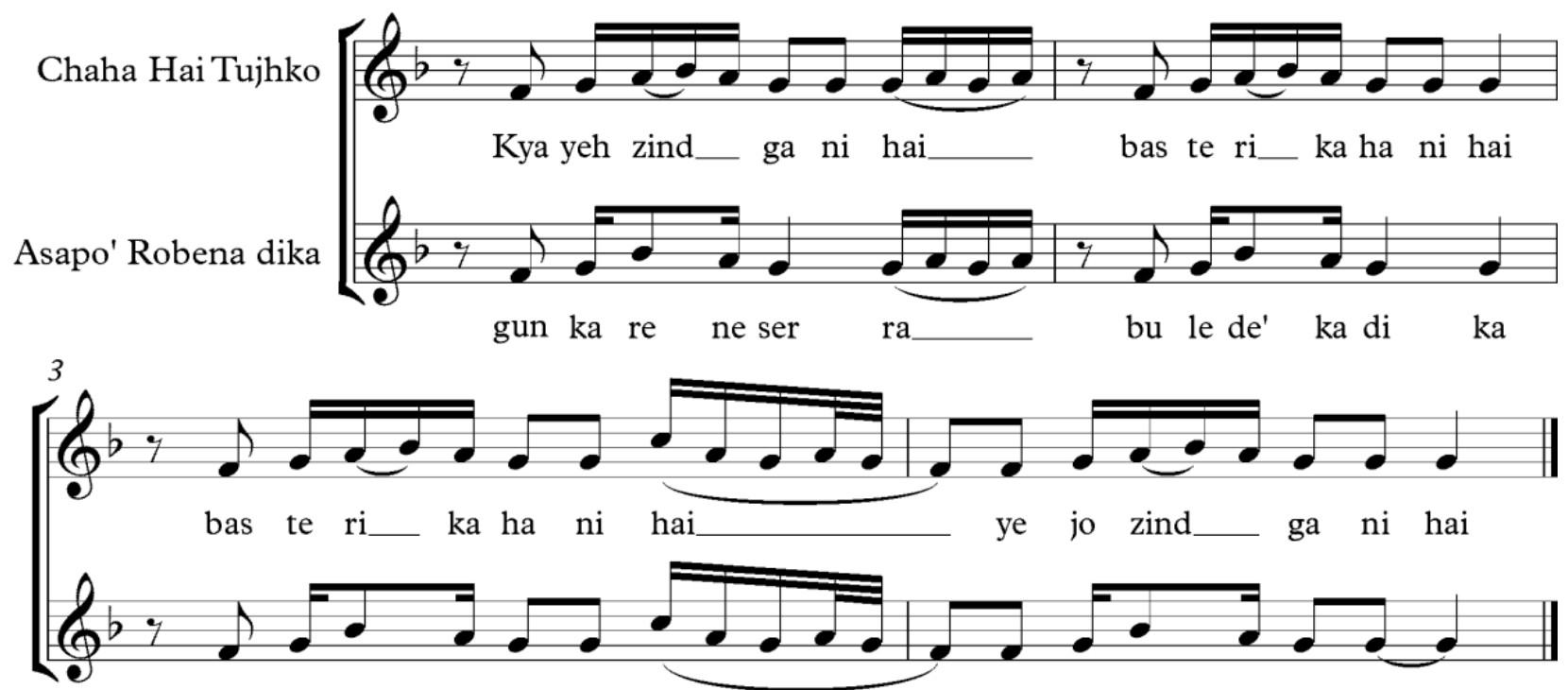

pe rak ka re e man na

bu le mon tak te $\mathrm{ka}$

\section{Keterangan : - Baris pertama adalah lagu asal}

- Baris kedua adalah lagu sasaran

Notasi 2. Contoh penyesuaian ritme pada lagu Asapo' Robena Dika yang mengadaptasi lagu Chaha Hai Tujhko

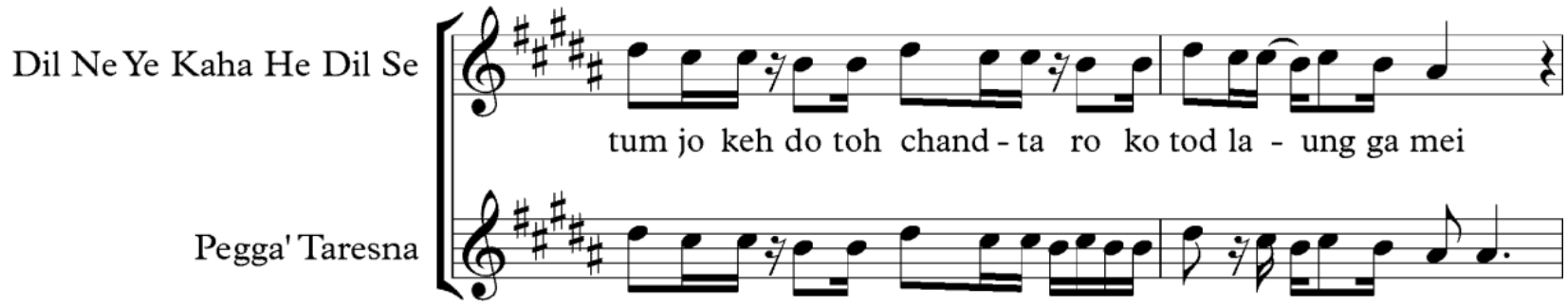

de' em ma du da'em ma a__ bu le se - a je len na

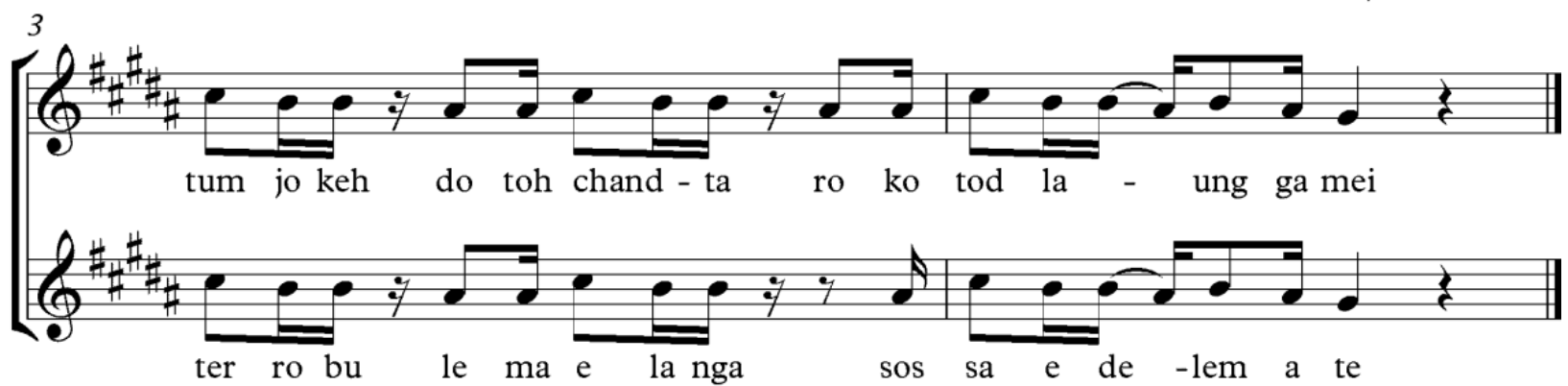

Keterangan :- Baris pertama adalah lagu asal

- Baris kedua adalah lagu sasaran

Notasi 3. Contoh penyesuaian ritme pada lagu Pegga' Taresna yang mengadaptasi lagu Dil Ne Ye Kaha Hai Dil Se 
dalam penerapannya selalu ada perubahan ritme. Perubahan tersebut merupakan penyesuaian ritme melodi vokal lagu asal ke lagu sasaran yang dipengaruhi penggunaan kosakata dalam lirik lagu sasaran. Keterbatasan kosakata dalam bahasa sasaran inilah yang mempengaruhi perubahan ritme pada melodi vokal, sehingga memaksakan penyesuaian ritme lagu asal dengan kosakata dalam lirik lagu sasaran.

\section{b. Perubahan Nada pada Melodi Vokal}

Menurut analisis data musik adaptasi dangdut Madura, perubahan nada pada melodi vokal lagu sasaran jarang ditemukan. Namun, terdapat beberapa lagu sasaran yang melakukan perubahan nada melodi vokal. Perubahan nada yang dilakukan tidak begitu mempengaruhi melodi vokal karena perubahan yang dilakukan hanya sedikit, sehingga kesan yang ditangkap masih tetap sama. Pada dasarnya posisi melodi vokal dalam lagu sasaran sangat penting dan melodi vokal inilah yang menjadi ciri khas musik dangdut Madura. Adapun perubahan nada melodi vokal ini dapat dilihat pada lagu
Abhekte yang mengadaptasi lagu Chaha Hai Tujbko dan lagu Maelang yang mengadaptasi lagu Sri Minggat. Contoh perbandingan lagu Abhekte terdapat pada notasi 4.

Perbandingan pada notasi 4 tersebut dapat dilihat bahwa perubahan melodi pada lagu sasaran tidak terlalu banyak. Secara umum, motif yang dipakai pada lagu sasaran hampir sama, hanya ada perubahan nada sedikit. Motif merupakan sepotongan lagu atau sekelompok nada yang merupakan suatu kesatuan dengan memuat arti dalam dirinya sendiri (Prier, 1996: 26) Perubahan nada yang paling kontras terlihat pada birama ketiga ketukan keempat sampai birama terakhir. Motif yang digunakan dalam lagu sasaran mengalami perubahan diikuti dengan nadanya. Dapat dikatakan bahwa perubahan nada melodi vokal pada lagu Abhekte hanya merupakan variasi dari pengembangan melodi asal, namun tidak membuat perubahan yang besar terhadap melodi asal. Perubahan nada melodi vokal yang lain terdapat dalam lagu Maelang. Adapun perubahan yang terjadi dalam melodi vokal pada notasi 5 .
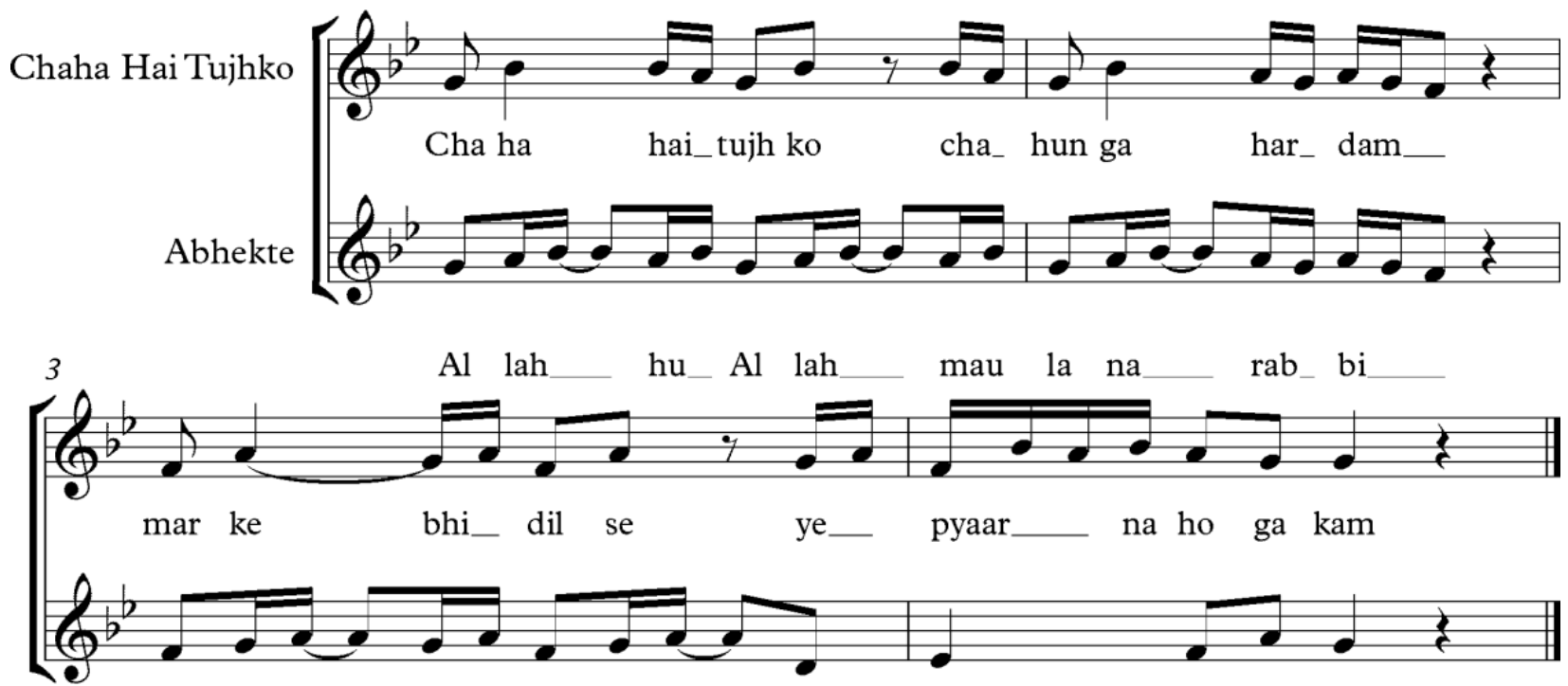
Al lah
$\mathrm{hu} \_\mathrm{Al}$ lah
mau
la
na has bi

\section{Keterangan :- Baris pertama adalah lagu asal \\ - Baris kedua adalah lagu sasaran}

Notasi 4. Contoh perubahan nada melodi vokal pada lagu Abhekte yang mengadaptasi lagu Chaha Hai Tujhko. 

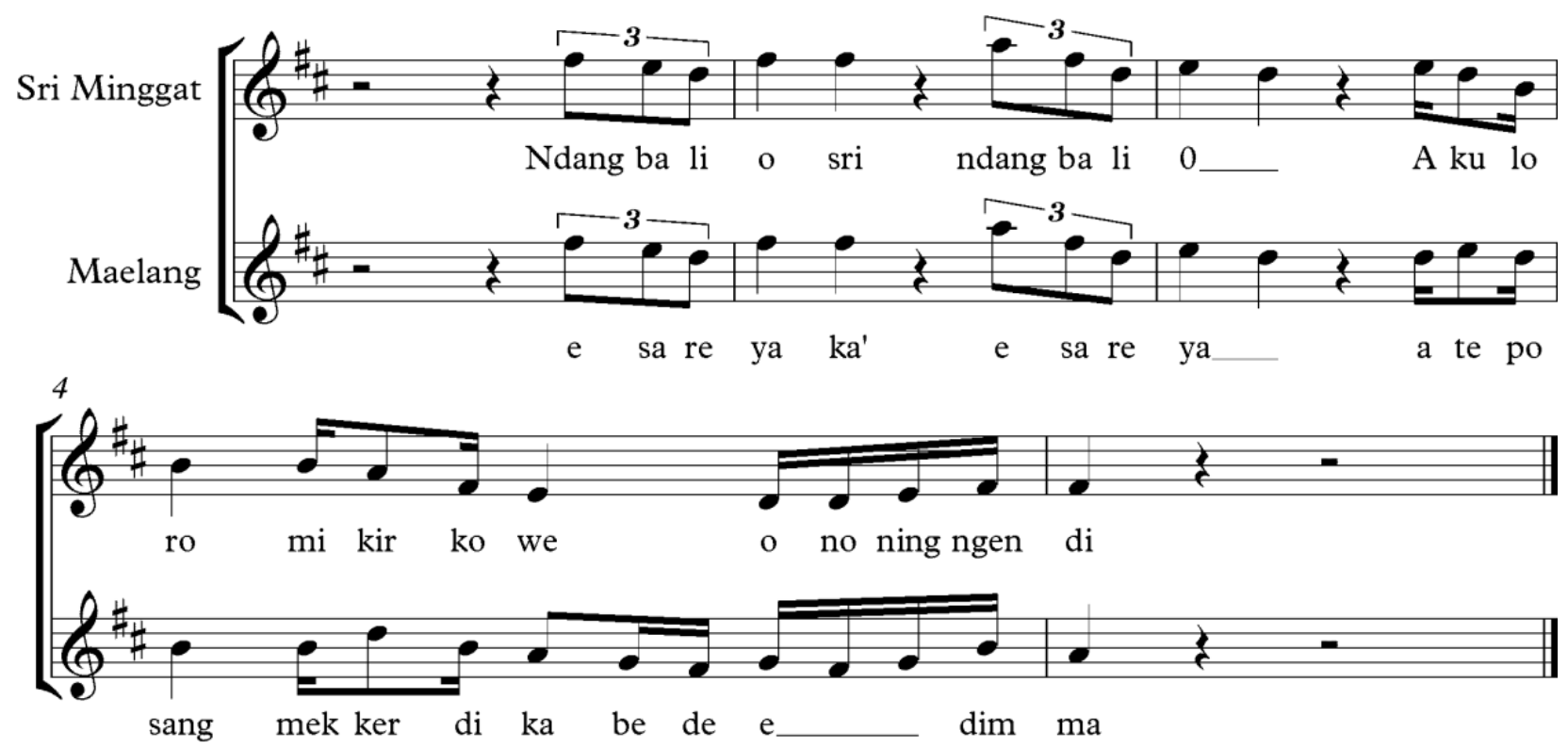

\section{Keterangan :- Baris pertama adalah lagu asal \\ - Baris kedua adalah lagu sasaran}

Notasi 5. Contoh perubahan nada melodi vokal pada lagu Maelang yang mengadaptasi lagu Sri Minggat.

Perbandingan nada pada notasi 5 tersebut dapat dikatakan perbedaan melodi asal dan melodi lagu sasaran tidak terlalu tampak. Secara umum ritme melodi vokal yang dipakai sama, namun perbedaan nadanya terdapat pada birama ketiga dan keempat. Dari beberapa contoh perbandingan lagu di atas, proses perubahan nada melodi vokal pada lagu dangdut Madura hanya merupakan variasi pengembangan melodi dari lagu asal dan tidak mempengaruhi perubahan melodi secara keseluruhan.

\section{Hubungan Antara Lirik dan Melodi Vokal Lagu Adaptasi Dangdut Madura}

Proses adaptasi musik Madura pada umumnya memiliki beberapa kecenderungan, dapat diamati melalui karya-karyanya. Dari beberapa karya yang telah dianalisis, kecenderungan yang sering dilakukan dalam lagu sasaran adalah: 1) syair/ lirik yang digunakan berusaha untuk disesuaikan dengan lagu asal. Proses penyesuaian tersebut sudah dibahas pada analisis sebelumnya, yaitu melalui pola liris, pola tiruan bunyi, pola penyesuaian bunyi, dan saduran. 2) Secara musikal selalu berorientasi untuk mempertahankan melodi vokal lagu asal kemudian melodi tersebut diadaptasi ke dalam lagu sasaran. Proses tersebut kemudian mengalami perubahan yaitu penyesuaian ritme melodi vokal dan perubahan nada melodi vokal.

Lirik dan melodi vokal memiliki hubungan yang saling mempengaruhi. Salah satu sisi kreativitas penggubah lagu sasaran adalah ketika dapat menyesuaikan melodi vokal dengan lirik yang diciptakan, sehingga menjadi kesatuan lagu yang harmonis. Melodi vokal dalam lagu sasaran selalu berorientasi untuk tetap dipertahankan, maka konsekuensi yang terjadi adalah pelaku adaptasi menciptakan lirik yang sesuai dengan melodi vokal lagu asal. Penciptaan lirik tersebut tentunya juga memperhatikan beberapa pola penyesuaian terhadap lirik lagu asal itu sendiri. Keterbatasan kosakata dalam bahasa sasaran memaksakan adanya perubahan melodi vokal lagu sasaran, yaitu penyesuaian ritme dan perubahan nada pada melodi vokal, namun karena melodi vokal sangat dipertahankan maka perubahan yang terjadi hanyalah sedikit dan tidak mengubah bentuk melodi vokal secara keseluruhan.

Proses perubahan dan penyesuaian tersebut tentunya tidak selalu sesuai dengan urutan di atas, tergantung dari kreativitas pelaku adaptasi. Pada 
intinya hubungan antara lirik dan melodi vokal yang saling mempengaruhi menjadi poin terpenting bagi pelaku adaptasi. Hal ini selalu diperhatikan untuk menciptakan karya yang harmonis dan ideal (Gambar 1).

\section{Penutup}

Berdasarkan analisis musikologis meliputi analisis lirik, melodi vokal, dan hubungan antara lirik dan melodi vokal, dapat diketahui pola-pola yang sering terjadi dalam proses adaptasi lagu asal ke lagu sasaran. Hasil penelitian ini menunjukkan bahwa: lirik lagu sasaran selalu menyesuaikan dengan lirik lagu asal, penyesuaian tersebut melalui penyesuaian a) pola liris, lagu sasaran menangkap pola rima pada lagu asal kemudian pola rima-nya disesuaikan ke dalam lagu sasaran. b) Pola tiruan bunyi (onomatope), pola bunyi yang dihasilkan oleh lirik lagu asal disesuaikan dengan pola bunyi lagu sasaran, namun bunyi yang dihasilkan oleh lirik tersebut tidak memiliki arti. c) Pola penyesuaian bunyi, pola bunyi yang dihasilkan oleh lirik lagu asal disesuaikan dengan bunyi yang terdapat dalam kosakata bahasa sasaran. Salah satu contohnya adalah kata Chaiyya dalam lagu asal menjadi Cia pada lagu sasaran. d) Saduran, lirik yang terdapat pada lagu asal diterjemahkan baik secara langsung atau kontekstual ke dalam bahasa sasaran.

Lagu sasaran selalu berorientasi untuk mempertahankan melodi vokal lagu asal. Penerapan melodi vokal lagu asal ke lagu sasaran mengalami beberapa penyesuaian. Melodi vokal dan lirik memiliki hubungan yang saling mempengaruhi dalam proses adaptasi lagu asal ke lagu sasaran. Melodi vokal lagu asal disesuaikan dengan penciptaan lirik lagu sasaran, tentunya lirik lagu sasaran juga disesuaikan dengan lirik lagu asal. Keterbatasan kosakata dalam bahasa sasaran memaksakan adanya perubahan melodi vokal yaitu penyesuaian ritme melodi vokal dan perubahan nada melodi vokal. Namun karena melodi vokal sangat dipertahankan maka perubahan yang terjadi hanyalah sedikit dan tidak mengubah bentuk melodi vokal secara keseluruhan.

Jadi keberadaan lirik dan melodi vokal dalam musik adaptasi dangdut Madura memiliki peran yang mendominasi untuk membentuk karakter dalam musiknya. Seperti halnya bagi setiap orang ketika mendengarkan sebuah lagu, yang pertama kali mereka tangkap dalam ingatan adalah lirik dan melodi vokal terlebih dahulu. Hal ini juga berlaku pada proses adaptasi yang dilakukan oleh para pelaku musik dangdut Madura.

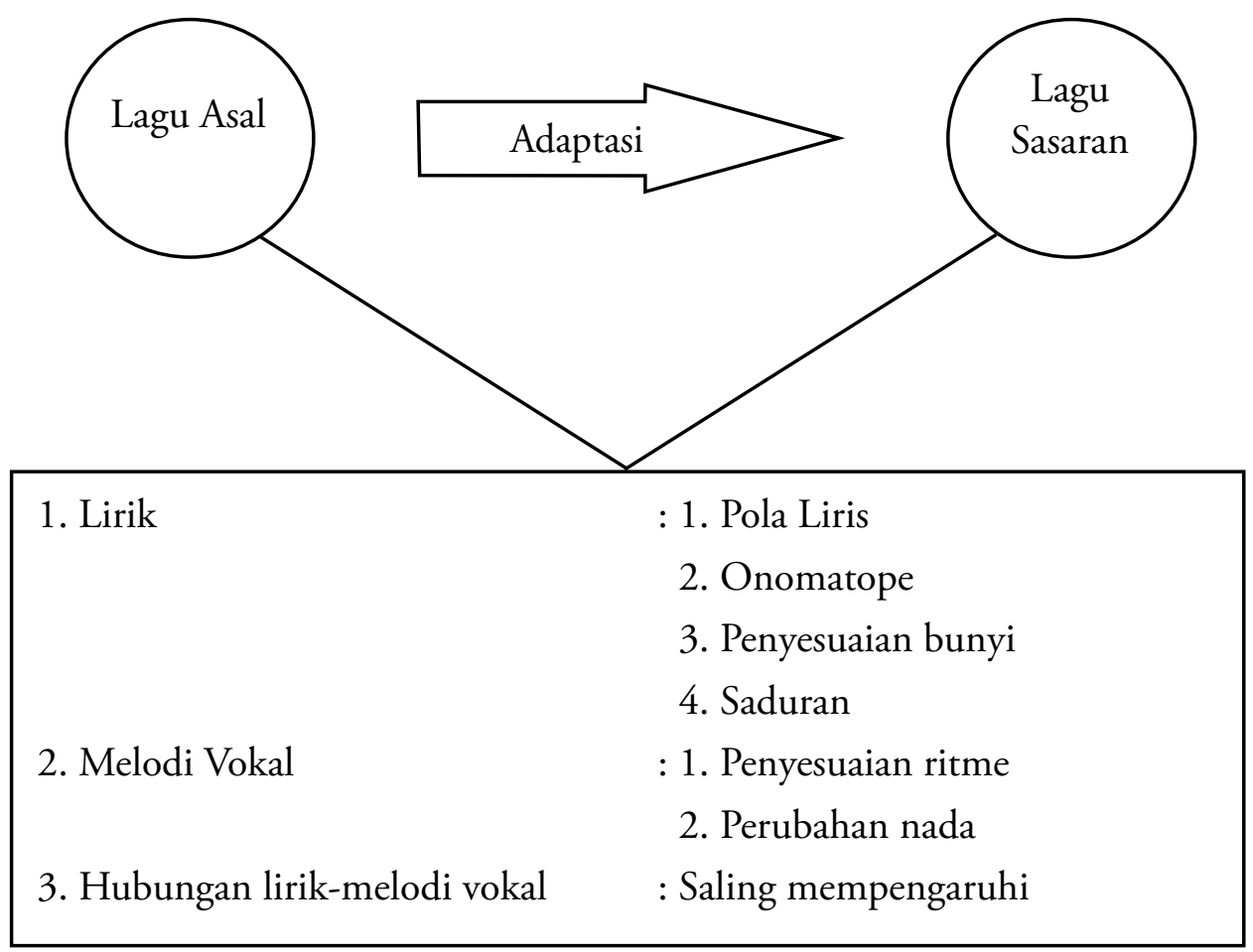

Gambar 1. Skema proses adaptasi dangdut Madura 


\section{Kepustakaan}

Chaer, Abdul. 2009. Pengantar Semantik Bahasa Indonesia. Jakarta: Rineka Cipta.

Frederick, William H. 1997. "Goyang Dangdut Rhoma Irama:Aspek-aspek Kebudayaan Pop Indonesia Kontemporer" dalam Idi Subandy Ibrahim(Ed). Ecstasy Gaya Hidup. Bandung:Mizan.

Heryanto, Ariel. 2012. "Budaya Pop dan Persaingan Identitas" dalam Ariel Heryanto (Ed). Budaya Populer di Indonesia Mencairnya Identitas Pasca-Orde Baru.Yogyakarta: Jalasutra

Hutcheon, Linda. 2006. A Theory of Adaptation. New York:Routledge

Mack, Dieter. 1995. Ilmu Melodi. Yogyakarta:Pusat Musik Liturgi.

Pradopo, Djoko Rachmat. 2005. Pengkajian Puisi. Yogyakarta: Gadjah Mada University Press.

Prier, Karl-Edmund. 1996. Ilmu Bentuk Musik. Yogyakarta: Pusat Musik Liturgi.

Salim, Agus. 2010. “Adaptasi Pola Ritme Dangdut pada Ansambel Perkusi” dalam RESITAL: JURNAL SENI PERTUNJUKAN, Volume 11 No. 2 Desember 2010: 106 -123.

Weintraub, Andrew N. 2012. Dangdut: Musik, Identitas, dan Budaya Indonesia. Jakarta: KPG (Kepustakaan Populer Gramedia)

Wibowo, Philipus Nugroho Hari. 2012. "AndeAnde Lumut: Adaptasi Folklor Ke Teater Epik Brecht" dalam RESITAL: JURNAL SENI PERTUNJUKAN, Volume 13 No.1 Juni 2012: $31-40$.

\section{Audio/Video}

https://www.youtube.com/

\section{Informan}

Anto (40 Tahun ). Operator (Sound Enginer) perusahaan rekaman lokal di Kabupaten Situbondo.

Angga (30 Tahun). Pelaku seni dan ketua divisi musik Dewan Kesenian Situbondo. 